УДК 633.11 (321). 003.13

(C) 2017

Рожсков А. О., доктор сільськогосподарських наук

Харківський національний аграрний університет ім. В. В. Докучаєва

Гутянський Р. А., кандидат сільськогосподарських наук

Інститут рослинництва ім. В. Я. Юр'єва НААН України

\title{
ДИНАМІКА ФОРМУВАННЯ ПЛОЩІ ЛИСТЯ РОСЛИН ЯЧМЕНЮ ЯРОГО ЗАЛЕЖНО ВІД ВПЛИВУ НОРМИ ВИСІВУ ТА ПОЗАКОРЕНЕВИХ ПІДЖИВЛЕНЬ
}

\section{Рецензент - доктор сільськогосподарських наук С. І. Попов}

У статті представлені результати досліджень, проведених протягом 2015, 2016 рр. на дослідному полі ХНАУ ім. В. В. Докучаєва щодо впливу норм висіву $і$ позакореневих підживлень на варіабельність показників площі листя $і$ зміну лінійних розмірів другого листка рослин ячменю ярого. Встановлено, щзо досліджувані варіанти норми висіву та позакореневих підживлень полімерним добривом «Вуксал» істотно впливали на площу листової поверхні рослин і лінійні розміри другого листка рослин ячменю ярого. Максимальні показники площі листя рослин у досліджувані фази розвитку забезпечувала норма висіву 5,0 $i$ 5,5 млн нас./2а. Крашим варіантом позакореневого підживлення посівів ячменю ярого, який забезпечував формування найбільшої площуі листя та максимальні лінійні розміри другого листка був варіант дворазового внесення препарату «Вуксал» - у фазу трубкування і колосіння в нормах 1,0 л/га.

Ключові слова: ячмінь ярий, норма висіву, позакореневі підживлення, площа листя, фази розвитку, полімерне добриво «Вуксал», фотосинтез.

Постановка проблеми. У структурі посівних площ Лісостепу ячмінь ярий займає близько $10 \%$. В окремі роки, коли приходиться пересівати загиблі площі пшениці озимої, частка ячменю ярого в структурі посівних площ зростає до $12-$ $15 \%$ [2]. Виходячи 3 цього, вивчення особливостей формування продуктивності ячменю за різних технологічних прийомів вирощування та погодних умов року є доволі актуальним і важливим завданням.

Аналіз останніх досліджень і публікацій, у яких започатковано розв'язання проблеми. Значна роль у вирішенні проблеми збільшення та стабілізації виробництва продукції зернових культур належить оптимізації норми висіву насіння та мінерального живлення стосовно певних агроекологічних умов [14].

Інтенсивність наростання площі листової поверхні і розмір складових іiї листків визначається насамперед густотою стояння рослин і вмістом поживних елементів у грунті. Як у загущених, так і в розріджених посівах погіршуються умови для нормального росту і розвитку рослин. Зокрема у загущених посівах зростає конкуренція як між рослинами, так і в межах самої рослини, а в розріджених посівах, хоч рослини і знаходяться в кращих умовах, проте вони не використовують повною мірою весь наявний агроресурс і крім того, водночас загострюється проблема забур'яненості посівів $[5,13]$.

Основним показником стану посівів як фотосинтезуючої системи $є$ ріст і розвиток їхніх листків $[7,16]$. Від розмірів і конфігурації розміщення листків залежать величина поглинутої посівом світлової енергії й сумарна транспірація.

Встановлення оптимальних норм висіву - це доволі відповідальний етап під час планування заходів технології вирощування зернових колосових $[1,3]$. М. А. Ламан та інші [8] представляють технологічні аспекти реалізації потенціалу продуктивності колосових культур, у яких норми висіву вважають одним з головних чинників впливу на синхронність розвитку рослин. На їхню думку, густота рослин $є$ одним 3 найважливіших інструментів управляння активністю наростання площі листків, характером ростових $\mathrm{i}$ формотворчих процесів.

Важливе значення у формуванні площі листя має система живлення рослин, особливо в пізні фази розвитку [11]. Дефіцит макро- та мікроелементів у рослинах зернових культур, як правило, спостерігається в період фази виходу в трубку та колосіння, що викликано активним наростанням рослинної біомаси. Позакореневі підживлення в ці фази розвитку сприяють формуванню більшої площі листя, активізують наростання біомаси рослин, забезпечують підвищення врожайності зерна і його якісних показників $[4,12]$.

Сучасна інтенсифікація рослинництва в умовах гострого дефіциту органічних добрив і занадто високих цін на мінеральні добрива передбачає розробку альтернативних заходів технології вирощування сільськогосподарських культур. У контексті цього все більшого значення набуває 


\section{СІЛЬСЬКЕ ГОСПОДАРСТВО. РОСЛИННИЦТВО}

вивчення впливу високоефективних полімерних хелатних добрив, біопрепаратів, регуляторів росту тощо у комплексі 3 іншими агротехнічними елементами на формування біометричних показників рослин, урожайність і якість продукції [10].

Мета досліджень полягала у встановленні комплексного впливу норми висіву та позакореневих підживлень посівів комплексними полімерними добривами на формування площі листя та лінійні розміри другого листка рослин ячменю ярого сорту Мономах селекції ХНАУ ім. В. В. Докучаєва в умовах східного Лісостепу України.

Методика досліджень. Дослідження проводили на дослідному полі Харківського національного аграрного університету на базі восьмипільної, зерно-паро-просапної сівозміни кафедри рослинництва протягом 2015, 2016 рр.

Грунти дослідного поля представлені чорноземами типовими слабозмитими. Вони характеризуються такими агрохімічними показниками: $\mathrm{pH}$ сольової витяжки - 6,45-7,00, загальний вміст гумусу в орному шарі - 5,5 \%, вміст Р2О5 102 мг на 1 кг грунту; К2О - 180 мг на 1 кг грунту.

Погодні умови району проведення досліджень доволі нестабільні і значно розрізняються за роками. Зокрема, кількість опадів за період вегетаціï 2015 і 2016 рр. становила 265 і 305 мм відповідно за середньо багаторічного показника 240 мм. У цілому сумарна кількість опадів була достатньою для нормального розвитку і формування високої урожайності рослин ячменю ярого. У той же час розподіл опадів по декадах вегетації був доволі нерівномірний, через що в окремі періоди розвитку рослини ячменю ярого відчували нестачу вологи.

Температурні показники періодів вегетації за роками досліджень дещо перевищували середньо багаторічні дані, водночас це дало можливість вивчити вплив досліджуваних чинників вирощування в реальних (типових), часто стресових умовах вегетації ярих колосових культур.

У дослідах вивчали вплив чотирьох варіантів норми висіву насіння (головні ділянки): 4,0, 4,5, 5,0, 5,5 млн шт./га і чотирьох варіантів позакореневих підживлень посівів полімерним добривом «Вуксал» (ділянки другого порядку): 1 - контроль (без проведення підживлень); 2 - позакореневе підживлення у фазу виходу рослин у трубку; 3 - позакореневе підживлення у фазу колосіння; 4 - дворазове проведення позакореневих підживлень (у фазу виходу рослин у трубку та у фазу колосіння). Норма внесення препарату «Вуксал» за один раз - 1,0 л/га.

«Вуксал» - полімерне добриво виробництва німецької компанії AGLUKON. Воно представляє собою концентровану суспензію 3 унікальною структурою і принципом дії, за рахунок вмісту мікроелементів у доступній хелатній формі.

Загальна площа досліду - 0,15 га. Площа посівної ділянки - 12 м², облікової - 10 м². Повторність у досліді чотириразова. Ширина захисних бічних смуг облікової ділянки - 0,5 м, кінцевих 1,0 м. Агротехніка вирощування ячменю ярого була загальноприйнятою для району проведення досліджень, окрім елементів поставлених на вивчення.

Результати досліджень. Виключно важливе значення для росту та розвитку рослин, а в підсумку - для рівня реалізації їхнього ресурсного потенціалу продуктивності, має площа листової поверхні [9].

Під час вивчення різних варіантів норми висіву потрібно враховувати певні особливості формування показників площі листової поверхні. В даному випадку слід враховувати, що в разі збільшення норми висіву, на фоні певного збільшення площі листової поверхні, сумарна площа листя однієї рослини буде зменшуватися, призводячи до зниження продуктивності окремо взятої рослини.

У проведених дослідженнях, площу листової поверхні рослин ячменю ярого залежно від впливу поставлених на вивчення норм висіву, визначали у фази кущіння, виходу в трубку, колосіння та цвітіння. Досліджувані варіанти норми висіву насіння забезпечували формування різних показників площі листя рослин. У фазу кущіння, в разі збільшення норми висіву, площа листової поверхні закономірно зростала. Зокрема, в середньому за роками досліджень, площа листової поверхні ячменю ярого за норм висіву насіння 4,0, 4,5, 5,0 і 5,5 млн шт./га становила 9,6, 10,7, 11,8 i 13,0 тис. м²/га відповідно (див. рис.).

Певної різниці впливу досліджуваних варіантів норми висіву на зміну площі листя рослин ячменю ярого у фазу кущіння залежно від впливу погодних умов не встановлено. Так, 3 підвищенням норми висіву 3 4,0 до 5,5 млн шт./га, площа листків у 2015 і 2016 pp. зростала на 34,0 i 35,7 \% відповідно.

У фазу трубкування інтенсивність наростання досліджуваного показника зі збільшенням норми висіву насіння з 4,0 до 5,5 млн шт./га, порівняно 3 попередньою фазою дещо зменшувалася. Так, якщо в період кущіння, зі збільшенням норми висіву насіння з 4,0 до 5,5 млн шт./га, площа листя рослин ячменю ярого зростала на $35,4 \%$, то в період виходу рослин у трубку - лише на $26,5 \%$. 


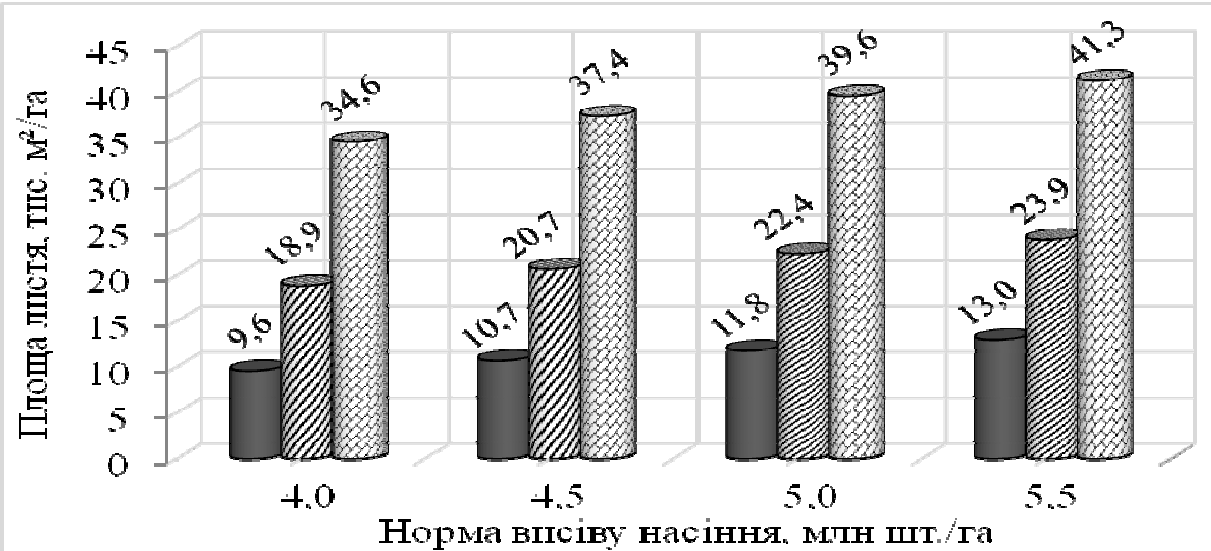

Рігунок. Дінаміка формування ппоші пाгетя ятменю ярого

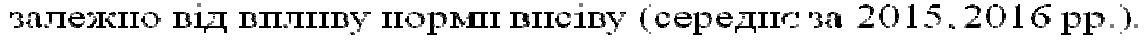

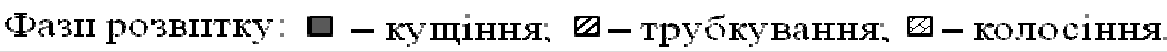

\section{1. Площа листя рослин ячменю ярого у фазу цвітіння залежно від впливу норми висіву} і проведення позакореневих підживлень, см² (середнє за 2015, 2016 рр.)

\begin{tabular}{|c|c|c|c|c|}
\hline \multirow{2}{*}{$\begin{array}{c}\text { Норма висіву, млн шт./га } \\
\text { (чинник А) }\end{array}$} & \multirow{2}{*}{$\begin{array}{c}\text { Bapiaнти підживлень* } \\
\text { (чинник В) }\end{array}$} & \multicolumn{2}{|c|}{ Рік } & \multirow{2}{*}{ Середнє } \\
\hline & & 2015 & 2016 & \\
\hline \multirow{4}{*}{4,0} & 1 & 35,1 & 36,5 & 35,8 \\
\hline & 2 & 36,0 & 37,2 & 36,6 \\
\hline & 3 & 35,1 & 36,9 & 36,0 \\
\hline & 4 & 36,3 & 37,0 & 36,7 \\
\hline \multirow{4}{*}{4,5} & 1 & 38,2 & 39,7 & 39,9 \\
\hline & 2 & 38,8 & 40,7 & 39,8 \\
\hline & 3 & 38,3 & 39,8 & 39,1 \\
\hline & 4 & 38,7 & 41,2 & 40,0 \\
\hline \multirow{4}{*}{5,0} & 1 & 40,2 & 41,9 & 41,1 \\
\hline & 2 & 41,3 & 42,4 & 41,9 \\
\hline & 3 & 40,5 & 42,0 & 41,1 \\
\hline & 4 & 41,5 & 42,5 & 42,0 \\
\hline \multirow{4}{*}{5,5} & 1 & 41,4 & 43,5 & 42,5 \\
\hline & 2 & 42,0 & 44,7 & 43,4 \\
\hline & 3 & 41,2 & 43,9 & 42,6 \\
\hline & 4 & 42,2 & 45,4 & 43,8 \\
\hline \multirow{4}{*}{$\begin{array}{c}\text { Середнє за нормою } \\
\text { висіву }\end{array}$} & 4,0 & 35,6 & 36,9 & 36,3 \\
\hline & 4,5 & 38,5 & 40,4 & 39,5 \\
\hline & 5,0 & 40,9 & 42,2 & 41,6 \\
\hline & 5,5 & 41,7 & 44,4 & 43,0 \\
\hline \multirow{4}{*}{$\begin{array}{c}\text { Середнє за варіантами } \\
\text { позакореневих } \\
\text { підживлень }\end{array}$} & 1 & 38,7 & 40,4 & 39,6 \\
\hline & 2 & 39,5 & 41,3 & 40,4 \\
\hline & 3 & 38,8 & 40,7 & 39,8 \\
\hline & 4 & 39,7 & 41,5 & 40,6 \\
\hline \multicolumn{2}{|l|}{ HIP $_{05}$ головного ефекту А } & 1,4 & 1,6 & - \\
\hline \multicolumn{2}{|l|}{$\mathrm{HIP}_{05}$ головного ефекту В } & 1,2 & 0,9 & - \\
\hline \multicolumn{2}{|l|}{$\mathrm{HIP}_{05}$ часткових порівнянь $\mathrm{A}$} & 1,9 & 2,1 & - \\
\hline \multicolumn{2}{|l|}{$\mathrm{HIP}_{05}$ часткових порівнянь В } & 1,7 & 1,5 & - \\
\hline
\end{tabular}

* - варіанти позакореневих підживлень: 1 - контроль (без підживлень); 2 - позакореневе підживлення препаратом «Вуксал» у фазу виходу рослин у трубку (1,0 л/га); 3 - підживлення препаратом «Вуксал» у фазу колосіння (1,0 л/га); 4 - дворазове підживлення препаратом «Вуксал»-у фазу трубкування (1,0 л/га) $i$ фазу колосіння (1,0 л/га). 


\section{СІЛЬСЬКЕ ГОСПОДАРСТВО. РОСЛИННИЦТВО}

У фази колосіння та цвітіння, за поступового підвищення норми висіву на один і той же показник, різниця між показниками площі листової поверхні поступово нівелюється, що можна пояснити дією наростаючої конкуренції між рослинами на чинники росту та розвитку. Наприклад, у фазу цвітіння, зі збільшенням норми висіву насіння 3 4,0 до 4,5 млн шт./га площа листя зростала на 8,1 \%, тоді як зі збільшенням норми висіву з 5,0 до 5,5 млн шт./га (на той самий показник - 0,5 млн шт./га) - лише на 4,3 \% (табл. 1).

Діапазон зміни показників площі листя у фазу цвітіння за впливу позакореневих підживлень посівів препаратом «Вуксал» був значно менший ніж за впливу норм висіву. Наприклад, максимальна розбіжність між показниками площі листя за впливу норми висіву в 2015 р. становила
6,1 тис. $\mathrm{m}^{2} /$ га $\left(\mathrm{HIP}_{05}-1,4\right.$ тис. $\mathrm{m}^{2} /$ га), тоді як за впливу позакореневих підживлень - лише 1,0 тис. $\mathrm{m}^{2} /$ га $\left(\mathrm{HIP}_{05}-1,2\right.$ тис. $\mathrm{M}^{2} /$ га). Статистично достовірний вплив позакореневих підживлень на площу листя ячменю ярого у фазу цвітіння відзначено тільки в більш сприятливому 2016 р. (максимальна розбіжність показників становила 1,1 тис. $\mathrm{m}^{2} /$ га за $\mathrm{HIP}_{05}-0,9$ тис. $\mathrm{m}^{2} /$ га). У цілому слід зазначити, що ранні позакореневі підживлення у фазу трубкування забезпечували, якщо не істотне зростання площі листя рослин у фазу цвітіння, то забезпечували тенденцію до ії зростання.

Найважливіше значення в асиміляційній роботі рослин, особливо в період формування і наливу зерна, має листя верхніх ярусів - верхній (прапорцевий) і другий від колосу (передпрапорцевий) [15].

\section{2. Площца другого листка ячменю ярого у фазу молочної стиглості залежно від впливу норми ви- сіву і проведення позакореневих підживлень рослин, см² (середнє за 2015, 2016 рр.)}

\begin{tabular}{|c|c|c|c|c|}
\hline \multirow{2}{*}{$\begin{array}{c}\text { Норми висіву, млн шт./га } \\
\text { (чинник А) }\end{array}$} & \multirow{2}{*}{$\begin{array}{c}\text { Bapiaнти підживлень* } \\
\text { (чинник В) }\end{array}$} & \multicolumn{2}{|c|}{ Рік } & \multirow{2}{*}{ Середне } \\
\hline & & 2015 & 2016 & \\
\hline \multirow{4}{*}{4,0} & 1 & 11,28 & 12,07 & 11,68 \\
\hline & 2 & 11,63 & 12,63 & 12,13 \\
\hline & 3 & 11,27 & 12,12 & 11,70 \\
\hline & 4 & 11,74 & 12,70 & 12,22 \\
\hline \multirow{4}{*}{4,5} & 1 & 11,07 & 11,84 & 11,46 \\
\hline & 2 & 11,46 & 12,51 & 11,99 \\
\hline & 3 & 11,04 & 11,80 & 11,42 \\
\hline & 4 & 11,58 & 12,44 & 12,01 \\
\hline \multirow{4}{*}{5,0} & 1 & 10,75 & 11,53 & 11,14 \\
\hline & 2 & 11,27 & 12,27 & 11,77 \\
\hline & 3 & 10,76 & 11,48 & 11,12 \\
\hline & 4 & 11,33 & 12,22 & 11,78 \\
\hline \multirow{4}{*}{5,5} & 1 & 10,34 & 11,21 & 10,77 \\
\hline & 2 & 10,96 & 11,86 & 11,41 \\
\hline & 3 & 10,42 & 11,14 & 10,78 \\
\hline & 4 & 11,04 & 11,93 & 11,49 \\
\hline \multirow{4}{*}{$\begin{array}{c}\text { Середнє за нормою } \\
\text { висіву }\end{array}$} & 4,0 & 11,48 & 12,38 & 11,93 \\
\hline & 4,5 & 11,29 & 12,15 & 11,72 \\
\hline & 5,0 & 11,03 & 11,88 & 11,46 \\
\hline & 5,5 & 10,69 & 11,54 & 11,12 \\
\hline \multirow{4}{*}{$\begin{array}{c}\text { Середнє за варіантами по- } \\
\text { закореневих } \\
\text { підживлень }\end{array}$} & 1 & 10,86 & 11,66 & 11,26 \\
\hline & 2 & 11,33 & 12,32 & 11,83 \\
\hline & 3 & 10,87 & 11,63 & 11,25 \\
\hline & 4 & 11,42 & 12,32 & 11,87 \\
\hline \multicolumn{2}{|l|}{$\mathrm{HIP}_{05}$ головного ефекту А } & 0,36 & 0,41 & - \\
\hline \multicolumn{2}{|l|}{ HІР $_{05}$ головного ефекту В } & 0,27 & 0,32 & - \\
\hline \multicolumn{2}{|l|}{ HIP $_{05}$ часткових порівнянь А } & 0,45 & 0,52 & - \\
\hline \multicolumn{2}{|l|}{$\mathrm{HIP}_{05}$ часткових порівнянь В } & 0,40 & 0,55 & - \\
\hline
\end{tabular}


Починаючи з фази колосіння, видалення пластинок нижніх листків, навіть якщо вони ще зелені, не спричиняє значного зниження врожайності зерна. Водночас видалення листових пластинок двох верхніх листків, навіть під час наливу зерна, призводить до різкого зниження врожайності (на 20-30 \%) і помітно знижує його якість [6].

У проведених нами дослідженнях були відмічені значні зміни площі листкової пластинки другого (передпрапорцевого) листка ячменю ярого залежно від досліджуваних варіантів норми висіву насіння. У середньому за варіантами проведення позакореневих підживлень посівів, площа листкової пластинки другого листка зі збільшенням норми висіву насіння 3 4,0 до 5,5

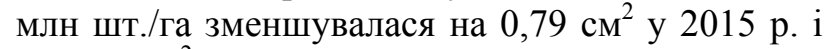
на $0,84 \mathrm{~cm}^{2}$ у 2016 р. (табл. 2).

Аналіз часткових порівнянь норми висіву насіння показав, що будь-якого закономірного впливу досліджуваних варіантів позакореневих підживлень на зміну ефективності впливу норми висіву насіння стосовно зміни показників площі другого листка не було. Зокрема, в погодних умовах 2016 р., площа другого листка, зі збільшенням норми висіву насіння 34,0 до 5,5 млн шт./га, на контрольному варіанті зменшувалася на 7,7 \%, на варіантах проведення позакореневих підживлень у фазу виходу в трубку - на $6,5 \%$, на варіантах проведення позакореневих підживлень у період наливу зерна - на 8,8 \% і на варіантах дворазових підживлень (у фази виходу в трубку і наливу зерна) - 6,5 \%. Аналогічна закономірність була встановлена і в 2015 р.

Подібним чином не було встановлено зміни ефективності впливу досліджуваних варіантів позакореневих підживлень рослин на варіабельність площі другого листка за різних варіантів норми висіву. Водночас аналіз головних ефектів досліджуваних варіантів позакореневих підживлень показав їхній істотний вплив на зміну площі листової пластинки другого листка.

Максимальних значень досліджуваний показник досягав на варіантах дворазових підживлень. Так, у середньому за нормами висіву, площа другого листка ячменю ярого після дворазової обробки посівів - у період виходу в трубку і колосіння, порівняно 3 контрольним варіантом зростала на $0,56 \mathrm{~cm}^{2}(5,2 \%)$ у 2015 р. і на 0,66 см$^{2}(5,7 \%)$ - у 2016 р. Як бачимо, ефект позакореневих підживлень на збільшення площі другого листка рослин ячменю ярого в проведених дослідженнях практично не залежав від погод- них умов. Більш раннє підживлення - в фазу трубкування, забезпечувало формування більшої площі листової пластинки другого листка рослин ячменю ярого. Пізні підживлення (у фазу колосіння) не мали істотного впливу на зміну лінійних розмірів уже практично сформованих передпрапорцевих листків. Можна припустити, що пізні позакореневі підживлення сприяють лише наливу зерна та покращенню його якісних показників за рахунок поглинання листками елементів живлення і їхнього транспортування у колос рослин.

Висновки. Результати проведених досліджень щодо впливу норм висіву та позакореневих підживлень комплексними полімерними добривами на динаміку наростання листової поверхні та лінійні розміри другого листка рослин ячменю ярого сорту Мономах дають підставу зробити такі висновки:

1. Досліджувані варіанти норми висіву і позакореневих підживлень полімерним добривом «Вуксал» істотно впливали на площу листової поверхні рослин і лінійні розміри передпрапорцевого листка ячменю ярого. Максимальні показники площі листя рослин у досліджувані фази розвитку відмічені на варіантах норми висіву 5,5 млн нас./га, проте прибавка показника за останнього підвищення норми висіву (3 5,0 до 5,5 млн нас./га) була найменшою через зростання конкуренції у посівах.

2. Кращим варіантом позакореневого підживлення, який забезпечував формування найбільшої площі листя та максимальні лінійні розміри другого листка був варіант дворазового внесення препарату «Вуксал» - у фазу трубкування і колосіння. А це створювало більш міцну основу для активізації асиміляційної діяльності рослин i, як наслідок, формування вищої урожайності зерна.

3. Певної закономірності взаємодії між досліджуваними елементами технології вирощування на варіабельність площі листя за фазами розвитку і зміну лінійних розмірів передпрапорцевого листка не встановлено.

Таким чином, норма висіву насіння на рівні 5,0 млн нас./га і позакореневі підживлення посівів полімерним добривом «Вуксал» у фази трубкування та колосіння сприяють формуванню більшої площі листя рослин, забезпечуючи повніше розкриття їхнього ресурсного потенціалу продуктивності. 


\section{БІБЛІОГРАФІЯ}

1. Авраменко Р. А. Влияние норм высева на полевую всхожесть и урожайность ярового ячменя: [сб. науч. тр.] / Р. А. Авраменко. - Днепропетровск, 1982. - Т. 80. - С. 80-84.

2. Анішин Л. А. Біостимулятори: урожай, якість і валові збори озимої пшениці / Л. А. Анішин // Новини захисту рослин. - 1998. - №9. - C. 30-31.

3. Борисоник 3. Б. Яровой ячмень / З. Б. Борисоник. - М. : Колос, 1974. - 254 с.

4. Гумінові добрива з мікроелементами - шлях до підвищення врожайності та якості / ТОВ «Агрофірма «Гермес» // Пропозиція. - 2009. - №6. C. 71 .

5. Завалин $A$. A. Формирование урожая и качество зерна ячменя и овса в зависимости от доз и сроков внесения азота / А. А. Завалин // Агрохимия. - 1996. - №11. - С. 20-26.

6. Кумаков В. А. Роль листьев разных ярусов в наливе колоса яровой пшеницы / В. А. Кумаков // тр. ГСХИ. - Вып.1. - 1954. - С. 43-58.

7. Куперман Ф. М. Биологический контроль за развитием растений на метеорологических станциях (микро фенология) / Ф. М. Куперман, Ю. И. Чирков. - Л., 1970. - 246 с.

8. Ламан Н. А. Биологический потенциал ячменя: Устойчивость к полеганию и продуктивность / Н. А. Ламан, Н. Н. Стасенко. - Минск : Наука и техника, 1984. - 216 с.

9. Лохачева О. А. Влияние фотосинтетических показателей на рост и развитие ячменя в услови- ях юга Приамурья / О. А. Лохачева, М. В. Маканинкова // Вестник Саратовского государственного аграрного университета им. Вавилова. 2012. - №4. - C. 22-27.

10. Формирование урожая основных сельскохозяйственных культур: кол. моногр. / пер. с чеш. З. К. Благовещенской. - М. : Колос, 1984. $367 \mathrm{c}$.

11. Подоба Л. В. Модифікуючий вплив різних біопрепаратів на основні параметри росту, розвитку і продуктивності ярого ячменю / Л. В. Подоба, Ю. В. Подоба // Вісник ХНАУ. - 2002. №5. - С. 222-229.

12. Псковский Г. Застосування добрив Еколист на зернових навесні / Г. Псковський // Пропозиція. -2007 . - №3. - С. 60-61.

13. Технологія вирощування ячменю ярого в умовах східної частини Лісостепу України: навч. посібник / уклад.: В. В. Кириченко, В. М. Костромітін, С. І. Попов та ін. ; [за ред. В. В. Кириченка]. - Х., 2011. - $168 \mathrm{c.}$

14. Усанова 3. И. Теория и практика создания высокопродуктивных посевов полевых культур / 3. И. Усанова. - Тверь : ТГСХА, 1999. - 330 с.

15. Стрижова Ф. М. Формирование площади листовой поверхности сортами яровой пшеницы / Ф. М. Стрижова // Вестн. Алтайск. гос. аграр. ун-та. - 2005. - №4 (20). - С. 16-19.

16. Якушкина Н. Л. Физиология растений / Н. Л. Якушкина. - М. : Колос, 1993. - 335 с. 